Article

\title{
Impacts of Moringa oleifera Foliage Substituted for Concentrate Feed on Growth, Nutrient Digestibility, Hematological Attributes, and Blood Minerals of Growing Goats under Abu Dhabi Conditions
}

\author{
Hany A. Zaher 1,2,*, Saeed A. Alawaash ${ }^{1}$, Amir M. Tolba ${ }^{1}$, Ayman A. Swelum 2,*(D), \\ Mohamed E. Abd El-Hack ${ }^{3}\left(\mathbb{D}\right.$, Ayman E. Taha ${ }^{4}$ (D) and Sameh A. Abdelnour ${ }^{5}$ \\ 1 Research and Development Division, Abu Dhabi Agriculture and Food Safety Authority, P.O. Box 52150, \\ Abu Dhabi, UAE \\ 2 Department of Theriogenology, Faculty of Veterinary Medicine, Zagazig University, Sharkia 44519, Egypt \\ 3 Poultry Department, Faculty of Agriculture, Zagazig University, Zagazig 44511, Egypt \\ 4 Department of Animal Husbandry and Animal Wealth Development, Faculty of Veterinary Medicine, \\ Alexandria University, Edfina 22758, Egypt \\ 5 Animal Production Department, Faculty of Agriculture, Zagazig University, Zagazig 44511, Egypt \\ * Correspondence: hany.zaher@gmail.com (H.A.Z.); aswelum@ksu.edu.sa (S.A.A.)
}

Received: 23 May 2020; Accepted: 9 July 2020; Published: 29 July 2020

check for updates

\begin{abstract}
To avoid the depletion and degradation of natural resources and to maintain long-term environmental quality and sustainability, the present study investigated the impacts of Moringa oleifera foliage (MF) as a replacement for concentrate feed on growth performance, blood hematology, serum metabolites, and serum mineral profile in growing goats. A total of 30 growing local goats (4 months old \pm 7 days, with an average weight of $15.80 \mathrm{~kg} \pm 147 \mathrm{~g}$ ), were randomly allotted to five treatment groups comprising $0 \%, 25 \%, 50 \%, 75 \%$, or $100 \%$ of MF replacing the concentrate feed as daily feed. The MF75 and MF100 percent diets decreased $(p<0.05)$ final body weight $(F B W)$, average daily gain (ADG), and crude protein (CP) of the diet. Moreover, $\mathrm{MF}$ up to $75 \%$ improved acid detergent fiber (ADF) digestibility. Feeding MF at different levels did not have any deleterious effects on blood chemistry parameters. Urea, low-density lipoprotein (LDL), and alkaline phosphatase (ALP) values were depressed $(p<0.05)$, due to increasing the MF (MF50, MF75, and MF100) level in the diet of growing goats kept in an arid region, when compared to the control group. Both of MF75 and MF100 led to a decrease $(p<0.05)$ in phosphorous $(\mathrm{P})$ level, compared with the other groups. The results were interpreted that feeding MF to replace $25 \%$ DM of the concentrate feed had no adverse effects on growth performance, feed utilization, serum metabolites, and serum minerals in growing goats reared under arid conditions. The increasing of MF level up to $50 \%$ or more significantly altered ADG and blood levels of creatinine, urea and ALP.
\end{abstract}

Keywords: Moringa oleifera; goats; growth; blood indices; arid conditions

\section{Introduction}

High environmental temperature is one of the most significant issues which threaten animals raised in tropical climates. In arid and tropical region, the environmental temperatures vary significantly throughout the year from approximately $10-44^{\circ} \mathrm{C}$ [1]. In the Arabian Peninsula, there is a growing scarcity of water and animal feed resources, which are the main restraints to increase livestock production. There is a substantial shortage in the number of crops available for feeding and feed ingredients for livestock, particularly during the summer season. In the majority of developing 
countries, the livestock industry has a substantial economic role, and it is indispensable for the food security of people [2]. Currently, global warming has severe negative impacts on several agricultural economic sectors, particularly on the livestock industry. It has been documented that tropical and subtropical regions are the areas most affected by global warming; these regions are described by high environmental temperatures for a long time over the year [2,3], which cause environmental heat stress for goats [4]. Moreover, it is characterized by a shortage of feed sources and water scarcities [2,3]. Therefore, producing forages with a high level of crude protein (CP) in these areas is a potential approach for the sustainability of the livestock industry. Abu Dhabi is the capital of the United Arab Emirates, which has a desert climate and high ambient temperature over the year. The Moringa oleifera foliage (MF) is widely used for animal nutrition because it is non-expensive source of protein for animal feeding and has the capability to be cultivated under different environmental and soil conditions $[5,6]$. The MF requires less water and resists harsh environmental condition. Moreover, dietary inclusion of MF in animal diets as a feedstuff is accepted for ruminants [7]. MF is best recognized for enhancing the synthesis of the microbial protein in the rumen and has high levels of naturally useful components such as minerals, vitamin C, flavonoids, tocopherols, and phenolic compounds [7-9].

Accordingly, there is a necessity for inexpensive protein source substitutes that are rich in amino acid constituents and can be generated abundantly and fast under the dry environments to meet requirements of livestock. Fodder shrubs and trees are considered as potential alternatives to ordinary high cost crops used in animal feeding because some of them have low-cost and consider good sources for protein that have been efficiently used for feeding small ruminants [10,11]. Besides, in the developing countries which have high environmental temperatures, superior production is very indispensable to fulfill the requirement, so the problem of nutritional deficiency must be solved [2]. The potential ecological heat stress has undesirable influences on growth performance, biochemical pathways, immune responses, electron balance, and physiological variables in animals [1,12].

The MF is an evergreen tree fodder and favorable as a substitute protein source that has been widely used for ruminant feeding [13]. The MF is broadly growing in the Arabian island because of its adaptability to various ecological environments and all sorts of soils in cultivable zones [14]. Therefore, the Moringa leaves are abundant throughout the year. The level of CP in MF leaf meal varies from 0.18 to $0.28 \mathrm{~kg} / \mathrm{kg}$ dry matter (DM) [8] and about $470 \mathrm{~g} / \mathrm{kg}$ of the CP is rumen undegradable protein $[15,16]$. Several reports confirmed that the inclusion of MF in the goat's diets gave a better productivity and growth performance compared to the $100 \%$ conventional diets such as sesame meal $[13,14]$. Recently, Moringa oleifera leaves are economically sustainable organic material, ecofriendly, and safe feed supplement for animals which improved growth, immunity. and contained antioxidant [17]. Moreover, Kholif et al. [18] indicated that feeding MF in an unconventional diet of up to $75 \%$ of DM, enhanced the ruminal fermentation, feed intake, and milk quality and quantity in lactating nubian goats under Egyptian conditions.

Since the desert and arid areas lack some crops that are used to feed animals and meet their requirements for growth and production, the depletion or degradation of natural resources can be avoided via using Moringa oleifera as a replacement of concentrate feed, which results in long-term environmental quality and sustainability. It is hypothesized that the feeding of MF at different levels can affect the growth performance, blood hematology, serum metabolites, and blood mineral profile of growing goats kept under arid conditions. Therefore, the present study aimed to evaluate the effect of feeding of MF at different levels on the growth performance, blood hematology, serum metabolites, and blood mineral profile of growing goats kept under arid conditions.

\section{Materials and Methods}

The current research was performed at Baniyas Research Station, Research and Development Division, Development Sector and Veterinary Laboratories Division, Animal Wealth Sector, Abu Dhabi Agriculture and Food Safety Authority, Abu Dhabi, United Arab Emirates. The authors confirm that the ethical policies of the journal, as noted on the journal's author guidelines page, have been adhered 
to, and the appropriate ethical review committee approval has been received. All procedures of the current study were followed according to the Directive 2010/63/EU of the European Parliament and the Council of 22 September 2010, on the safety of animals used for scientific purposes. The experimental protocol regarding the care and handling of animals had been approved by the Ethics Committee of the Research and Development Division, Development Sector, Abu Dhabi Agriculture and Food Safety Authority.

\subsection{Moringa Preparation and Chemical Composition}

Sufficient amounts of MF plants were cultivated at the research station at Baniyas, Abu Dhabi, United Arab Emirates. Drip irrigation was used which presumably improves the soil water regime thus leading to higher crop yields. The crop was available for the whole year with high rate in winter season. Approximately two months following seeding, and when plants have gotten a height of 0.65 to $0.70 \mathrm{~m}$, a homogeneity cut was performed (at 5 to $7 \mathrm{~cm}$ cutting height). For this exact trial, MF biomass (collected from stems, branches, thin twigs, and leaves) were collected daily at morning, mixed with the commercial concentrate feed, and alfalfa hay at different levels and then directly presented to the animals. The ingredients of the commercial concentrate feed were barley, yellow corn, soybean meal, wheat bran, sodium bicarbonate, molasses, lime stone, salt, monocalcium phosphate, mycotoxin binder, vitamins and minerals premixes, anticoccidials, and other essential feed additives (Ruminant Animal Ration, National Feed and Flour Production and Marketing Co. L.L.C., Abu-Dhabi, UAE). The calculated analysis of the commercial concentrate feed on DM basis was DM $\geq 87 \%$, ash $\leq 11 \%$, $\mathrm{CP} \geq 15 \%$, crude fat $\geq 2.2 \%$, $\mathrm{ADF} \leq 25 \%$, NDF $\leq 40 \%$, and $\mathrm{TDN} \geq 63 \%$. The proximate nutrients composition of commercial concentrate feed, alfalfa hay, and MF, which was used in the animal diet, are presented in Table 1.

Table 1. The nutrient composition of Moringa oleifera, commercial concentrate feed and alfalfa experimental diets $(n=5 /$ feed type).

\begin{tabular}{cccc}
\hline Feed Type & Concentrate Feed & Alfalfa Hay & Moringa \\
\hline Dry matter $(\%)$ & 93.03 & 93.21 & 24.36 \\
ADF (\%) & 30.28 & 29.49 & 28.86 \\
Crude protein $(\%)$ & 9.44 & 14.19 & 18.38 \\
P (\%) & 0.53 & 0.32 & 0.33 \\
K (\%) & 0.74 & 2.34 & 1.63 \\
Ca (\%) & 0.29 & 0.48 & 2.2 \\
Mg (\%) & 0.29 & 0.48 & 0.27 \\
S (\%) & 0.84 & 0.47 & 1.36 \\
Na (\%) & 0.04 & 0.16 & 0.07 \\
Fe (ppm) & 838 & 549 & 331 \\
Cu (ppm) & 10.6 & 12.8 & 9.7 \\
Mn (ppm) & 70.57 & 33.84 & 30.38 \\
Zn (ppm) & 55.18 & 31.12 & 26.1 \\
Cr (ppm) & 5.61 & 4.76 & 3.47 \\
Se (ppm) & 0.23 & 0.12 & ND \\
\hline
\end{tabular}

ADF: acid detergent fiber, P: phosphorus; K: potassium; Ca: calcium; Mg: magnesium; S: sulphur; Na: sodium; Fe: iron; $\mathrm{Cu}$ : copper; Mn: manganese; Zn: zinc; Cr: chromium; Se: selenium.

\subsection{Animal, Design, and Alimentation}

A total of 30 growing local goats (4 months old \pm 7 days) with an average weight of $15.80 \mathrm{~kg} \pm 147 \mathrm{~g}$ were included in the study. Goats had a clinically normal, healthy appearance after physical examination by veterinarian (body temperature, grazing ability, ruminal activity, limbs and moving activities and examination of mouth and mucous membrane of eyes). Goats were kept outdoors with shelter (60\% covered of the farm) through the day and kept in a semi-open barn at nighttime. Ad libitum drinking water was offered throughout the day. The animals were fed a set amount per day with a 
constant of alfalfa hay (1200 g/day), and replacement concentrate feed by MF plants at different levels $(0 \%, 25 \%, 50 \%, 75 \%$, or $100 \%)$ to meet the nutritional requirements for growing goats [19]. Goats were randomly allocated into five groups as following: (1) control group goats were fed the control diet formed from alfalfa hay and concentrate feed without any Moringa oleifera foliage (MF0); (2) MF25 goats were fed with 25\% MF replacing 25\% of the concentrate feed, (3) MF50, goats were fed with $50 \%$ of MF replacing $50 \%$ of the concentrate feed, (4) MF75, goats were fed with $75 \%$ of MF replacing $75 \%$ of the concentrate feed; and (5) MF100, goats were fed with $100 \%$ of MF replacing $100 \%$ of the concentrate feed (Table 2). All diet components were thoroughly mixed to attain the homogenous addition level. Feeding treatments were applied for 12 consecutive weeks (April-June). The first four weeks were assumed as an adaptive period with data collection occurring in weeks 5-12.

Table 2. Ingredients compound of the growing goat's diets reared under hot environmental temperature.

\begin{tabular}{cccccc}
\hline \multirow{2}{*}{ Items } & DFots \\
\cline { 2 - 6 } & MF0 & MF25 & MF50 & MF75 & MF100 \\
\hline Concentrate Feed & $1700 \mathrm{~g}$ & $1300 \mathrm{~g}$ & $850 \mathrm{~g}$ & $500 \mathrm{~g}$ & - \\
Alfalfa Hay & $1200 \mathrm{~g}$ & $1200 \mathrm{~g}$ & $1200 \mathrm{~g}$ & $1200 \mathrm{~g}$ & $1200 \mathrm{~g}$ \\
Moringa Oleifera & - & $400 \mathrm{~g}$ & $850 \mathrm{~g}$ & $1200 \mathrm{~g}$ & $1700 \mathrm{~g}$ \\
\hline
\end{tabular}

Moringa oleifera added at $0 \%$ (MF0), 25\% (MF25), 50\% (MF50), 75\% (MF75), and (MF100), replacing 0\%, 25\%, 50\%, $75 \%$, and $100 \%$ of concentrate feed, respectively, as daily feed.

\subsection{Temperature Humidity Index (THI)}

Throughout the study period, relative humidity (\%) and ambient temperatures in Celsius degrees were recorded daily in the goat farm by an automatic thermo-hygrometer at mid-day (14:30). The THI was calculated according to LPHSI [20] as the subsequent calculation:

$$
\mathrm{THI}=\mathrm{db}{ }^{\circ} \mathrm{F}-\left\{(0.55-0.55 \mathrm{RH})\left(\mathrm{db}{ }^{\circ} \mathrm{F}-58\right)\right\},
$$

where $\mathrm{RH}$ is the relative humidity as a percentage and $\mathrm{db}{ }^{\circ} \mathrm{F}$ is dry bulb temperature measured in Celsius degrees and converted to Fahrenheit degrees. The values of THI were calculated and then considered as follows: $<82=$ absence of heat stress, $82-<84=$ moderate heat stress, $84-<86=$ severe heat stress and 86 and more = very severe heat stress.

\subsection{Growth Performance and Digestibility}

Live body weight (LBW) was measured weekly and the average daily gain (ADG) was determined based on the method described by Sultana et al. [21]. To determinate LBW, all goats were weighed at the start and weekly until the end of the trial duration (5 and 12 weeks, respectively). Feed intake was recorded daily by weighing of the offered diets and refusals from the previous day. By the end of the experiment (the last week), animals in each group (six/group) were independently housed in metabolic cages for seven days for the digestibility experiment. Feces were collected from each animal, dried in oven at $60{ }^{\circ} \mathrm{C}$ for $24 \mathrm{~h}$, and stored for laboratory analysis. The apparent coefficients of crude protein (CP) and acid detergent fiber (ADF) digestibility were determined using direct method. The apparent crude protein $(\mathrm{CP})$ and acid detergent fiber (ADF) digestibility coefficients of the diets were determined according to the classical formula:

Apparent nutrient $(\mathrm{CP}$ or $\mathrm{ADF})$ digestibility $(\%)=\{($ nutrient $(\mathrm{CP}$ or $\mathrm{ADF})$ intake - nutrient $(\mathrm{CP}$ or $\mathrm{ADF})$ excreted)/nutrient $(\mathrm{CP}$ or $\mathrm{ADF})$ intake $\times 100$.

\subsection{Hematological and Serum Biochemical Analysis}

By the end of the experiment period, from each animal, two blood samples ( $7 \mathrm{~mL}$ each) were collected from the jugular vein; the first one was separated into an EDTA tube for hematology analysis using Sysmex XT 2000i (VLD-DPM-CBC-06, Mundelein, IL 60060, USA) for determination of the 
counts of erythrocytes, hematocrit, hemoglobin concentration, leucocytes, differential leucocytic count including neutrophils, lymphocytes, monocytes, eosinophils and basophils percentages. The hematological indices, including mean corpuscular volume (MCV), mean corpuscular hemoglobin (MCHC), and mean corpuscular hemoglobin concentration (MCHC), were measured during analysis. The other blood sample was collected into a tube (without EDTA) and kept for $20 \mathrm{~min}$ at room temperature to coagulate, then centrifuged (Centrifuge 400R, Kendrew, Osterode, Germany) for $10 \mathrm{~min}$ at $3000 \mathrm{rpm}$ to isolate the serum. The obtained serum was stored at $-20{ }^{\circ} \mathrm{C}$ until further analysis (within two weeks) for the estimation of certain minerals and biochemical analysis. The serological concentration of creatinine (Crea), total protein (TP), albumin (ALB), urea (BUN), creatinine kinase (CK), alanine aminotransferase (ALT), aspartate aminotransferase (AST), low-density lipoprotein (LDL), alkaline phosphatase (ALP), and gamma-glutamyl-transferase (GGT) were assessed using Beckman Coulter analyzers (VLD-DPM-CBC-02, Mundelein, IL 60060, USA) and commercial diagnostic kits (Shimadzu, Kyoto, Japan), according to manufacturer instructions. Sodium, potassium, chloride, iron, copper, zinc phosphorus and calcium serum concentrations were determined using ion-selective electrodes (ISE) module of the Roche/Hitachi cobas c systems (Model c501).

\subsection{Statistical Analysis}

The results were statistically analyzed using a one-way analysis of variance (ANOVA) test in simple randomized design by the SPSS program (Chicago, IL, USA). Means were established for significant differences using Duncan's multiple range test at a level of $p=0.05$.

\section{Results}

\subsection{Temperature Humidity Index (THI)}

As presented in Figure 1, throughout the whole experimental period, the THI values ranged from 91.3 to 94 , demonstrating a very severe level of heat stress. Moreover, the total value of THI during the current study was 92.2 , reflecting a state of very severe heat stress.

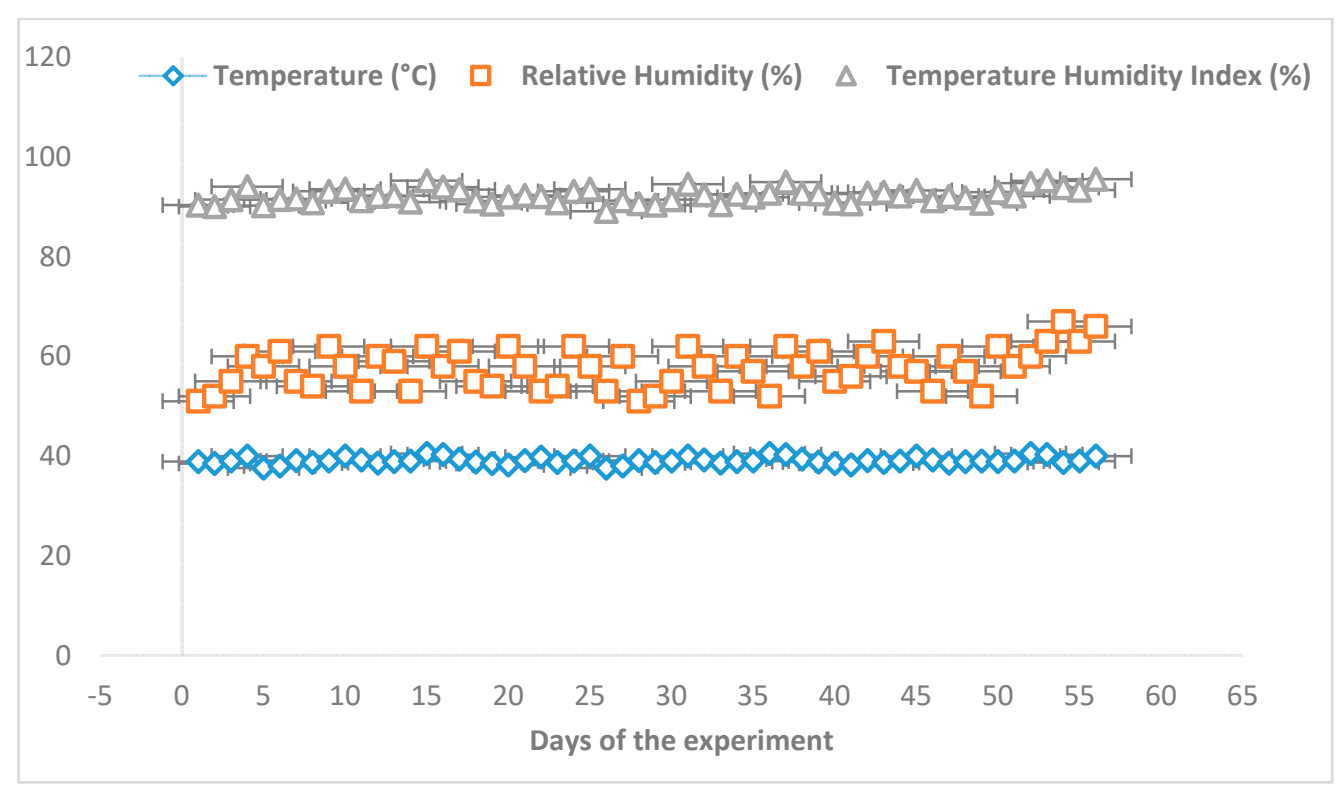

Figure 1. Temperature, humidity and temperature humidity index throughout the experimental period in Abu Dhabi, United Arab Emirates. 


\subsection{Growth Performance}

The impacts of the replacement of concentrate feed with MF in growing goat under heat stress conditions are presented in Table 3. By the end of the research, the LBW and ADG values were significantly higher in MF0 and MF25 groups than MF75 and MF100 groups. Furthermore, no significant differences in the LBW and ADG were found between the MF0 and MF25 groups (Table 3). Concerning acid detergent fiber (ADF) and crude protein $(\mathrm{CP})$ digestibility, the goats fed MF25, MF50 and MF75 levels had increased ADF $(p=0.010)$ digestibility compared to the control. At the same time, no significant influence was recorded among MF0, MF25, and MF50 treatments for CP (\%) digestibility. High MF (75 and 100\%) replacement in goat diets had undesirable impacts $(p=0.043)$ on the digestibility of CP, compared to the control.

Table 3. Growth performance and digestibility of crude protein and acid detergent fiber in growing goats fed diets with different levels of Moringa oleifera replacing concentrate feed.

\begin{tabular}{cccccccc}
\hline \multirow{2}{*}{ Items } & MF0 & MF25 & MF50 & MF75 & MF100 & Pooled \\
SEM & p-Value \\
\cline { 2 - 6 } & \multicolumn{7}{c}{ Growth performance } \\
\hline IBW (kg) & 15.83 & $15.75^{a}$ & 15.77 & 15.73 & 15.78 & 0.147 & $>0.999$ \\
FBW (kg) & $20.06^{\mathrm{a}}$ & $19.81^{\mathrm{a}}$ & $18.63^{\mathrm{ab}}$ & $17.25^{\mathrm{b}}$ & $17.05^{\mathrm{b}}$ & 0.334 & 0.001 \\
ADG (kg) & $0.083^{\mathrm{a}}$ & $0.080^{\mathrm{a}}$ & $0.056^{\mathrm{b}}$ & $0.030^{\mathrm{c}}$ & $0.025^{\mathrm{c}}$ & 0.005 & $<0.001$ \\
\hline \multicolumn{7}{c}{ Digestibility of crude protein and acid detergent fiber (\% on DM basis) } \\
\hline ADF (\% of DM) & $52.30^{\mathrm{b}}$ & $57.25^{\mathrm{a}}$ & $57.07^{\mathrm{a}}$ & $58.09^{\mathrm{a}}$ & $55.24^{\mathrm{ab}}$ & 0.62 & 0.010 \\
CP (\%) & $9.13^{\mathrm{ab}}$ & $9.43^{\mathrm{a}}$ & $8.98^{\mathrm{abc}}$ & $7.61^{\mathrm{bc}}$ & $7.25^{\mathrm{c}}$ & 0.28 & 0.043 \\
\hline
\end{tabular}

Pooled SEM; pooled standard error of the mean. Moringa oleifera added at 0\% (MF0), 25\% (MF25), 50\% (MF50), $75 \%$ (MF75), and $100 \%$ (MF100), replacing $0 \%, 25 \%, 50 \%, 75 \%$, and $100 \%$ of concentrate feed, respectively. IBW; initial body weight; FBW; final body weight; ADG; daily body weight gain; ADF, acid detergent fiber; CP, crude protein. Means in the same row with no letters after them or with a common superscript letter following them are not significantly different $(p>0.05)$.

\subsection{Hematological Analysis}

The influences of the replacement of concentrate feed with MF on blood hematological variables in growing goats reared under arid conditions are presented in Table 4 . All hematological variables were not statistically $(p>0.05)$ different at various treatment levels. However, the $\mathrm{Hb}$ level was significantly $(p=0.009)$ higher in the MF25 group than MF50 and MF100 groups.

\subsection{Serum Metabolites}

The effects of feeding MF at different levels in growing goats reared under arid conditions on serum metabolites are presented in Table 5 . All the serum metabolites assessments were statistically $(p<0.01)$ changed by the nutritional management except for bilirubin, creatinine kinase (CK), aspartate aminotransferase (AST) and gamma-glutamyl-transferase (GGT). For creatinine (Crea), urea (BUN), and alkaline phosphatase (ALP), values were depressed $(p<0.05)$, with increasing MF (MF50, MF75, and MF100) in the diet of growing goats kept under the arid region in comparison with the control group. On the other side, the glucose level was significantly increased $(p=<0.001)$ in MF75 and MF100 groups than other treated and control groups. Albumin (ALB) level was significantly lower in MF0 and MF25 groups than other groups. Alanine aminotransferase (ALT) level was significantly higher in MF25 and MF100 groups than MF50. Low density Lipoprotein (LDL) levels were significantly higher in MF0 and MF50 groups than the control and the other groups. Under high environmental conditions, feeding growing goats on MF at different levels caused a significant reduction in creatinine and urea. Creatinine and urea were indicators mainly for the differences in CP digestibility between the diet and also for kidney function. 
Table 4. Blood hematology in growing goats fed diets with different levels of Moringa oleifera replacing concentrate feed.

\begin{tabular}{cccccccc}
\hline \multirow{2}{*}{ Items } & \multicolumn{9}{c}{ Diets } & Pooled & $p$ Value \\
\cline { 2 - 6 } & MF0 & MF25 & MF50 & MF75 & MF100 & SEM & \\
\hline HTC $(\%)$ & 30.31 & 32.43 & 32.42 & 33.01 & 31.14 & 0.51 & 0.447 \\
$\mathrm{Hb}(\mathrm{g} / \mathrm{dL})$ & $14.43^{\mathrm{ab}}$ & $15.34^{\mathrm{a}}$ & $14.15^{\mathrm{b}}$ & $14.45^{\mathrm{ab}}$ & $13.38^{\mathrm{b}}$ & 0.19 & 0.009 \\
$\mathrm{RBCs}\left(10^{6} / \mu \mathrm{L}\right)$ & 12.62 & 12.44 & 12.72 & 13.25 & 11.61 & 0.19 & 0.117 \\
$\mathrm{MCV}(\mathrm{fL})$ & 24.31 & 25.43 & 25.58 & 25.12 & 24.53 & 0.32 & 0.529 \\
$\mathrm{MCH}(\mathrm{pg})$ & 11.43 & 11.15 & 11.37 & 11.40 & 11.22 & 0.07 & 0.682 \\
$\mathrm{MCHC}(\mathrm{g} / \mathrm{dL})$ & 47.72 & 44.77 & 44.75 & 45.72 & 45.33 & 0.56 & 0.456 \\
WBCs & 12.92 & 13.37 & 15.74 & 14.66 & 14.68 & 0.36 & 0.990 \\
$\left(10^{3} / \mu \mathrm{L}\right)$ & 61.32 & 73.25 & 63.38 & 69.05 & 66.02 & 1.75 & 0.218 \\
NEU $(\%)$ & 30.21 & 21.91 & 27.43 & 24.72 & 27.42 & 1.37 & 0.414 \\
LYPH (\%) & 4.71 & 2.35 & 3.47 & 3.45 & 3.23 & 0.32 & 0.249 \\
MONO (\%) & 2.78 & 2.83 & 3.28 & 1.88 & 2.13 & 0.19 & 0.146 \\
ESOIN (\%) & 1.03 & 0.83 & 0.87 & 0.88 & 0.72 & 0.50 & 0.410 \\
BASO (\%) & &
\end{tabular}

Pooled SEM; pooled standard error of the mean. Moringa oleifera added at $0 \%$ (MF0), 25\% (MF25), 50\% (MF50), 75\% (MF75), and (MF100), replacing $0 \%, 25 \%, 50 \%, 75 \%$, and $100 \%$ of concentrate feed, respectively. HCT: hematocrit; $\mathrm{Hb}$ : hemoglobin; RBCs: red blood cells; MCV: Mean corpuscular volume; $\mathrm{MCH}$ : mean corpuscular hemoglobin; MCHC; mean corpuscular hemoglobin concentration; WBCs: white blood cells; LYM: lymphocytes; NEU, neutrophil; LYPH, lymphocytes; MONO, monocytes; ESOIN, eosinophil; BASO, basophils. Means in the same row with no letters after them or with a common superscript letter following them are not significantly different $(p>0.05)$.

Table 5. Serum metabolites in growing goats fed diets with different levels of Moringa oleifera replacing concentrate feed.

\begin{tabular}{|c|c|c|c|c|c|c|c|}
\hline \multirow{2}{*}{ Items } & \multicolumn{5}{|c|}{ Diets } & \multirow{2}{*}{$\begin{array}{c}\text { Pooled } \\
\text { SEM }\end{array}$} & \multirow{2}{*}{$p$ Value } \\
\hline & MF0 & MF25 & MF50 & MF75 & MF100 & & \\
\hline $\begin{array}{l}\text { Glucose } \\
\text { (mg/dL) }\end{array}$ & $40.93^{b}$ & $42.21^{b}$ & $43.32^{b}$ & $48.67^{\mathrm{a}}$ & $50.24^{a}$ & 0.971 & $<0.001$ \\
\hline $\begin{array}{l}\text { Bulirubin } \\
(\mu \mathrm{mol} / \mathrm{L})\end{array}$ & 22.80 & 24.23 & 25.02 & 25.04 & 24.91 & 0.374 & 0.288 \\
\hline Crea $(\mathrm{mg} / \mathrm{dL})$ & $0.69^{a}$ & $0.66^{\mathrm{a}}$ & $0.59^{b}$ & $0.597^{b}$ & $0.6^{\mathrm{b}}$ & 0.010 & $<0.001$ \\
\hline $\mathrm{TP}(\mathrm{g} / \mathrm{dL})$ & $6.25^{b}$ & $6.50^{b}$ & $7.06^{\mathrm{a}}$ & $6.96^{\mathrm{a}}$ & $7.01^{\mathrm{a}}$ & 0.072 & $<0.001$ \\
\hline $\operatorname{ALB}(\mathrm{g} / \mathrm{dL})$ & $3.45^{\mathrm{c}}$ & $3.483^{c}$ & $3.6 b^{c}$ & $3.8^{\mathrm{a}}$ & $3.7^{\mathrm{ab}}$ & 0.041 & $<0.001$ \\
\hline BUN (mg/dL) & $54.95^{\mathrm{a}}$ & $53.92^{\mathrm{a}}$ & $49.86^{b}$ & $49.85^{b}$ & $50.33^{b}$ & 0.484 & $<0.001$ \\
\hline $\mathrm{LDL}(\mathrm{mg} / \mathrm{dL})$ & $487.66^{\mathrm{a}}$ & $397.54^{b}$ & $464.21^{\mathrm{a}}$ & $360.16^{b}$ & $387.83^{b}$ & 10.48 & $<0.001$ \\
\hline CK (IU/L) & 295.21 & 318.83 & 351.72 & 360.01 & 337.30 & 12.97 & 0.545 \\
\hline ALT (IU/L) & $14.21 \mathrm{ab}$ & $16.05^{\mathrm{a}}$ & $13.23^{b}$ & $14.84^{\mathrm{ab}}$ & $16.11^{\mathrm{a}}$ & 0.351 & 0.032 \\
\hline AST (IU/L) & 89.56 & 82.63 & 79.76 & 79.73 & 73.88 & 1.97 & 0.149 \\
\hline ALP (IU/L) & $206.66^{a}$ & $196.83^{a}$ & $158.16^{b}$ & $134.16^{b}$ & $151.66^{b}$ & 6.93 & $<0.001$ \\
\hline GGT (IU/L) & 73.66 & 74.16 & 68.00 & 77.83 & 73.83 & 1.927 & 0.642 \\
\hline
\end{tabular}

Pooled SEM; pooled Standard error of the mean. Moringa oleifera added at $0 \%$ (MF0), 25\% (MF25), 50\% (MF50), $75 \%$ (MF75), and (MF100), replacing $0 \%, 25 \%, 50 \%, 75 \%$ and $100 \%$ of concentrate feed, respectively. Creatinine: Crea; total protein: TP; albumin: ALB; urea: BUN; creatinine kinase: CK; alanine aminotransferase: ALT; aspartate aminotransferase: AST; low-density lipoprotein: LDL; alkaline phosphatase, ALP; gamma-glutamyl-transferase: GGT. Means in the same row with no letters after them or with a common superscript letter following them are not significantly different $(p>0.05)$.

\subsection{Minerals}

As shown in Table 6, phosphorus $(\mathrm{P})$, zinc $(\mathrm{Zn})$, and chloride $(\mathrm{Cl})$ were significantly influenced by MF (MF75 and MF100) replacement. Calcium (Ca), sodium (Na), iron ( $\mathrm{Fe})$, potassium $(\mathrm{K})$, and copper $(\mathrm{Cu})$ levels were not statistically affected by MF feeding at different levels. Both the MF75 and MF100 treatments decreased $(p<0.05)$ the $\mathrm{P}, \mathrm{Zn}$, and $\mathrm{Cl}$ concentrations in serum, compared to the other groups. 
Table 6. Serum minerals in growing goats fed diets with different levels of Moringa oleifera replacing concentrate feed.

\begin{tabular}{|c|c|c|c|c|c|c|c|}
\hline \multirow{2}{*}{$\begin{array}{l}\text { Items } \\
\mu \mathrm{g} / \mathrm{dL}\end{array}$} & \multicolumn{5}{|c|}{ Diets } & \multirow{2}{*}{$\begin{array}{c}\text { Pooled } \\
\text { SEM }\end{array}$} & \multirow{2}{*}{$p$-Value } \\
\hline & MF0 & MF25 & MF50 & MF75 & MF100 & & \\
\hline $\mathrm{Ca}$ & 10.68 & 11.05 & 10.73 & 11.02 & 10.85 & 0.085 & 0.24 \\
\hline $\mathrm{P}$ & $8.45^{\mathrm{a}}$ & $8.51^{\mathrm{a}}$ & $8.73^{a}$ & $7.43^{b}$ & $7.11^{b}$ & 0.19 & 0.01 \\
\hline $\mathrm{Na}$ & 149.32 & 151.53 & 153.21 & 150.83 & 149.3 & 0.50 & 0.09 \\
\hline $\mathrm{Fe}$ & 145.23 & 143.41 & 142.51 & 153.38 & 154.5 & 4.53 & 0.88 \\
\hline $\mathrm{K}$ & 5.87 & 5.67 & 5.85 & 5.65 & 5.34 & 0.067 & 0.08 \\
\hline $\mathrm{Cu}$ & 83.51 & 85.66 & 78.02 & 77.53 & 78.33 & 2.05 & 0.65 \\
\hline $\mathrm{Zn}$ & $68.67^{\mathrm{ab}}$ & $66.83^{a b}$ & $70.50^{\mathrm{a}}$ & $58.33^{b c}$ & $53.33^{c}$ & 2.01 & 0.02 \\
\hline $\mathrm{Cl}$ & $106.01^{b}$ & $107.26^{a b}$ & $108.7^{\mathrm{a}}$ & $105.43^{b}$ & $105.33^{b}$ & 0.42 & 0.04 \\
\hline
\end{tabular}

Pooled SEM; pooled Standard error of the mean. Moringa oleifera added at $0 \%$ (MF0), 25\% (MF25), 50\% (MF50), $75 \%$ (MF75), and (MF100), replacing $0 \%, 25 \%, 50 \%, 75 \%$ and $100 \%$ of concentrate feed, respectively. Means in the same row with no letters after them or with a common superscript letter following them are not significantly different $(p>0.05)$.

\section{Discussions}

In the present study, we observed good growth performance of heat-stressed goats reared under tropical and subtropical conditions, especially with MF25 treatment. Both MF75 and MF100 had negative influences on the FBW and ADG. It was thought that the high level of MF in the diets comprises various anti-nutritional compounds, such as phytates, tannins, cyanide, and oxalates, which may affect the digestion, metabolism, and absorption of nutrients in animals [22,23]. This reduction in growth performance parameters might be due to reducing the digestibility of CP. Kholif et al. [18] perceived enhanced palatability of MF comparative to sesame meal in the lactating goat's diets. Conversely, Sultana et al. [24] reported that the use of $100 \%$ MF in Bengal goats feed significantly improved the growth performance, $\mathrm{CP}$, and ADF digestibility. Moreover, MF diets improved ADF resulting in faster digesta outflow rate and decreased gut fill from the rumen [19].

It is broadly recognized that hematological attributes can be considered to assess animal health conditions proficiently and to assist in identifying various environmental stresses [25]. Concerning the present findings, none of the group treatments were adversely affected the blood indices. Previous results indicated that the use of the ethanolic extract of MF roots [26], aqueous extract of MF leaves [25], or aqueous extract of MF roots [26] enhanced the hematological variables of animals. No significant differences were detected in various blood parameters for MF treated and control groups. These records disagreed with the trial in mice which confirmed that the administration of M. oleifera significantly augmented the count of WBCs, particularly the percentage of neutrophils [27]. The results revealed significant decrease in urea levels in goats supplemented with MF diets at levels of $50 \%, 75 \%$ and $100 \%$ and this could result in a powerful antimicrobial and fungicidal activities [11,28].

The serum biochemical attributes were within the normal range in all groups which received MF, representing the normal status of kidney and liver found in Meel et al. [32]. These finding are consistent with observations reported by the previous reports [17,18]. Values of blood glucose, $\mathrm{TP}$, and albumin were significantly higher in the MF treatments; these results may be attributed to better CP digestibility [14]. The increased of glucose level with increased with MF in diets of goats may be due to higher organic matter digestibility, energy concentration, propionic acid, and total VFA [18]. Similar results were reported in lactating goats that fed fresh MF [17]. On the other hand, several reports confirmed the hypoglycemic effect of M. oleifera [29-31]. Our findings partially agreed with Meel et al., [32] who reported that replacing the concentrate feed with the of leaves M. oleifera in Sirohi goat kids increased hemoglobin, RBC, PCV, serum total protein, globulin, and albumin level while serum glucose level decreased.

For liver enzymes, the present study confirmed lower ALP enzyme activities in goats fed MF at $50 \%, 75 \%$, and $100 \%$ levels. The significant decrease of such enzyme activity may be attributed to the 
anti-inflammatory and antioxidant effects of $M$. oleifera, which contains high levels of phenolic acid and flavonoids [33]. Moringa oleifera leaf extract ameliorated liver injury induced by methotrexate in male rats by decreasing serum liver enzymes as ALT, AST, ALP, and GGT [34]. The increasing MF level in diet resulted in a reduction in kidney function parameters, which may be due to decreasing of $\mathrm{CP}$ content of the diet [35].

The MF has favorable effects on health status due to its constituents of minerals with minor anti-nutritional components [18]. Similarly, under Saudi Arabian conditions, Al-Juhaimi et al. [17] found that the inclusion of $25 \% \mathrm{MF}$ into the diets of lactating goats significantly improved the immunity status of animals. The authors suggested that the high level of phenolic compounds in MF might have a potential strategy to reduce the negative influences of the tropical environment in Abu Dhabi conditions. On the other hand, microelements have beneficial effects in maintaining cellular physiological functions Arigony et al., [36]. As mentioned in Table 1, MF contains a high number of microelements such as Zn, $\mathrm{Mn}$, and $\mathrm{Cu}$ that play vital roles as antioxidant agents during heat stress conditions [37]. Supplementing the diets of heat-stressed animals with microelements enhanced the antioxidant defense and reduced the deleterious impressions of the hot ambient temperature $[1,38,39]$

The antioxidant activity of MF could be attributed to the existence of significant quantities of minerals (phosphorus: $204 \mathrm{mg}$; zinc: $6.7 \mathrm{mg}$ ), as well as the presence of the other bioactive constituents with probable antioxidant effect, such as phytol and isobenzofuran-1-one-3-acetic acid [18]. Replacement of concentrate feed with MF up to $25 \%$ in growing goat diets had no deleterious effects on growth indices, digestibility, blood hematology, serum minerals, and metabolites reared under desert conditions.

\section{Conclusions}

It could be concluded that the replacement of concentrate feed with Moringa oleifera foliage (MF) by up to $25 \%$ of growing goat diets reared under the desert conditions of Abu Dhabi had no deleterious effects on growth indices, digestibility, blood hematology, and serum minerals. These affirmative marks propose the presence of MF as fodder crop substitute in animal feed concentrate, particularly in arid and dry areas such as the United Arab Emirates, where the cultivation of soybean and other concentrate feed is challenging due to water insufficiency. Depletion or degradation of natural resources can be avoided by using MF in replacement of concentrate feed which will resulting in long-term environmental quality and sustainability. Further studies are needed for assessment of sustainability after using alternative food sources to traditional concentrates.

Author Contributions: H.A.Z., S.A.A. (Saeed A. Alawaash), and A.M.T. conceived, designed, and performed the experiments; M.E.A.E.-H. analyzed the data; A.A.S. and S.A.A. contributed to analysis tools; H.A.Z., A.E.T., M.E.A.E.-H., A.A.S., and S.A.A. (Sameh A. Abdelnour) wrote the paper. All authors have read and agreed to the published version of the manuscript.

Funding: This research received a fund from Abu Dhabi Agriculture and Food Safety Authority

Acknowledgments: Members of the Research and Development Division, Development Sector, Abu Dhabi Agriculture and Food Safety Authority for their support and encouragement.

Conflicts of Interest: The authors declare no conflict of interest.

\section{References}

1. Abdelnour, S.A.; Abd El-Hack, M.E.; Khafaga, A.F.; Arif, M.; Taha, A.E.; Noreldin, A.E. Stress biomarkers and proteomics alteration to thermal stress in ruminants: A review. J. Therm. Biol. 2019, 79, 120-134. [CrossRef]

2. FAO. World Livestock 2011-Livestock in Food Security; FAO: Rome, Italy, 2011.

3. FAO. The State of Food and Agriculture Climate Change, Agriculture and Food Security 2016, Livestock in food Security; FAO: Rome, Italy, 2016.

4. Al-Samawi, K.A.; Al-Hassan, M.J.; Swelum, A.A. Thermoregulation of female Aardi goats exposed to environmental heat stress in Saudi Arabia. Indian J. Anim. Res. 2014, 48, 344-34911. [CrossRef] 
5. Ashour, E.A.; El-Kholy, M.S.; Alagawany, M.; Abd El-Hack, M.E.; Mohamed, E.; Mohamed, L.A.; Taha, A.E.; El Sheikh, A.I.; Laudadio, V.; Tufarelli, V. Effect of dietary supplementation with Moringa oleifera leaves and/or seeds powder on production, egg characteristics, hatchability and blood chemistry of laying Japanese quails. Sustainability 2020, 12, 2463. [CrossRef]

6. Abd El-Hack, M.E.; Alagawany, M.; Elrys, A.S.; Desoky, E.M.; Tolba, H.M.N.; Elnahal, A.S.M.; Elnesr, S.S.; Swelum, A.A. Effect of forage Moringa oleifera L. (moringa) on animal health and nutrition and its beneficial applications in soil, plants and water purification. Agriculture 2018, 8, 145. [CrossRef]

7. Nouman, W.; Basra, S.M.A.; Siddiqui, M.T.; Yasmeen, A.; Gull, T.; Alcayde, M.A.C. Potential of Moringa oleifera L. as livestock fodder crop: A review. Turk. J. Agric. For. 2014, 38, 1-14. [CrossRef]

8. Mendieta-Araica, B.; Spörndly, R.; Reyes-Sánchez, N.; Spörndly, E. Moringa (Moringa oleifera) leaf meal as a source of protein in locally produced concentrates for dairy cows fed low protein diets in tropical areas. Livest. Sci. 2011, 137, 10-17. [CrossRef]

9. Soliva, C.R.; Kreuzer, M.; Foidl, N.; Foidl, G.; Machmüller, A.; Hess, H.D. Feeding value of whole and extracted Moringa oleifera leaves for ruminants and their effects on ruminal fermentation in vitro. Anim. Feed Sci. Technol. 2005, 118, 47-62. [CrossRef]

10. Moyo, B.; Masika, P.J.; Muchenje, V. Effect of supplementing crossbred Xhosa lop-eared goat castrates with Moringa oleifera leaves on growth performance, carcass and non-carcass characteristics. Trop. Anim. Health Prod. 2012, 44, 801-809. [CrossRef]

11. Aregheore, E.M. Intake and digestibility of Moringa oleifera-batiki grass mixtures by growing goats. Small Rumin. Res. 2002, 46, 23-28. [CrossRef]

12. Abd El-Hack, M.E.; Abdelnour, S.A.; Taha, A.E.; Khafaga, A.F.; Arif, M.; Ayasan, T.; Swelum, A.A.; Abukhalil, M.H.; Alkahtani, S.; Aleya, L.; et al. Herbs as thermoregulatory agents in poultry: An overview. Sci. Total Environ. 2020, 703, 134399. [CrossRef]

13. Kholif, A.E.; Gouda, G.A.; Morsy, T.A.; Salem, A.Z.M.; Lopez, S.; Kholif, A.M. Moringa oleifera leaf meal as a protein source in lactating goat's diets: Feed intake, digestibility, ruminal fermentation, milk yield and composition, and its fatty acids profile. Small Rumin. Res. 2015, 129, 129-137. [CrossRef]

14. Kholif, A.E.; Morsy, T.A.; Gouda, G.A.; Anele, U.Y.; Galyean, M.L. Effect of feeding diets with processed Moringa oleifera meal as protein source in lactating Anglo-Nubian goats. Anim. Feed Sci. Technol. 2016, 217, 45-55. [CrossRef]

15. Abd Mahfuz, S.; Piao, X.S. Application of Moringa (Moringa oleifera) as natural feed supplement in poultry diets. Animals 2019, 9, 431. [CrossRef]

16. Becker, K. Studies on utilization of Moringa oleifera leaves as animal feed. Inst. Anim. Prod. Trop. Subtrop. 1995, 480, 15.

17. Al-Juhaimi, F.Y.; Alsawmahi, O.N.; Abdoun, K.A.; Ghafoor, K.; Babiker, E.E. Antioxidant potential of Moringa leaves for improvement of milk and serum quality of Aardi goats. South Afr. J. Bot. 2019. [CrossRef]

18. Kholif, A.E.; Gouda, G.A.; Olafadehan, O.A.; Abdo, M.M. Effects of replacement of Moringa oleifera for berseem clover in the diets of Nubian goats on feed utilisation, and milk yield, composition and fatty acid profile. Animal 2018, 12, 964-972. [CrossRef]

19. National Research Council; Committee on the Nutrient Requirements of Small Ruminants; Board on Agriculture; Division on Earth; Life Studies. Nutrient Requirements of Small Ruminants: Sheep, Goats, Cervids, and New World camelids; China Legal Publishing House: Beijing, China, 2007.

20. LPHSI. Livestock and Poultry Heat Stress Indices: Agriculture Engineering Guide; Clemson 744 University: Clemson, SC, USA, 1990.

21. Sultana, N.; Alimon, A.; Huque, K.; Baba, M.; Hossain, J. Evaluation of Moringa Foliage (Moringa oleifera) as Goat Feed. Iran. J. App. Anim. Sci. 2015, 5, 865-871.

22. Association of Official Analytical Chemists. Official Methods of Analysis: Changes in Official Methods of Analysis Made at the Annual Meeting; Supplement; Association of Official Analytical Chemists: Washington, DC, USA, 1990; Volume 15.

23. Su, B.; Chen, X. Current Status and Potential of Moringa oleifera Leaf as an Alternative Protein Source for Animal Feeds. Front. Vet. Sci. 2020, 7, 53. [CrossRef]

24. Sultana, N.; Alimon, A.; Huque, K.; Sazili, A.; Yaakub, H.; Hossain, J.; Baba, M. The feeding value of Moringa (Moringa oleifera) foliage as replacement to conventional concentrate diet in Bengal goats. Adv. Anim. Vet. Sci. 2015, 3, 164-173. [CrossRef] 
25. Ewuola, E.O.; Sokunbi, O.A.; Sanni, K.M.; Oyedemi, O.M.; Lawal, T.T. Haematological and serum biochemical responses of rabbit does to crude Moringa oleifera leaf extract at gestation and lactation. Trop. Anim. Health Prod. 2015, 47, 637-642. [CrossRef]

26. Hashem, N.M.; Soltan, Y.A.; El-Desoky, N.I.; Morsy, A.S.; Sallam, S.M.A. Effects of Moringa oleifera extracts and monensin on performance of growing rabbits. Livest. Sci. 2019, 228, 136-143. [CrossRef]

27. Gupta, A.; Gautam, M.K.; Singh, R.K.; Kumar, M.V.; Rao, C.; Goel, R.K.; Anupurba, S. Immunomodulatory effect of Moringa oleifera Lam. extract on cyclophosphamide induced toxicity in mice. Indian J. Exp. Biol. 2010, 48, 1157-1160. [PubMed]

28. Yusuf, A.O.; Mlambo, V.; Iposu, S.O. A nutritional and economic evaluation of Moringa oleifera leaf meal as a dietary supplement in West African Dwarf goats. S. Afr. J. Anim. Sci. 2018, 48, 81-87. [CrossRef]

29. Villarruel-López, A.; López-de la Mora, D.A.; Vázquez-Paulino, O.D.; Puebla-Mora, A.G.; Torres-Vitela, M.R.; Guerrero-Quiroz, L.A.; Nuño, K. Effect of Moringa oleifera consumption on diabetic rats. BMC Complement. Altern. Med. 2018, 18, 127. [CrossRef]

30. Vargas-Sánchez, K.; Garay-Jaramillo, E.; González-Reyes, R.E. Effects of Moringa oleifera on glycaemia and insulin levels: A review of animal and human studies. Nutrients 2019, 11, 2907. [CrossRef]

31. Aju, B.Y.; Rajalakshmi, R.; Mini, S. Protective role of Moringa oleifera leaf extract on cardiac antioxidant status and lipid peroxidation in streptozotocin induced diabetic rats. Heliyon 2019, 5, e02935. [CrossRef]

32. Meel, P.; Gurjar, M.L.; Nagda, R.K.; Sharma, M.C.; Gautam, L. Effect of Moringa oleifera leaves feeding on hemato-biochemical profile of Sirohi goat kids. J. Entomol. Zool. Studies. J. Entomol. Zool. Stud. 2018, 6, $41-48$.

33. Ndukaku, O.Y.; Emmanuel, E.U.; Mercy, E.A.; Caroline, N.O. Evaluation of the serum liver enzymes markers, lipid profile and kidney function parameters in typhoid patients. IJTDH 2015, 8, 79-89. [CrossRef]

34. Yousef, F.M.A.; Khattab, H.A.H.; Sindi, H.A.A. Effectiveness of Moringa oleifera L. Leaves Extract Against Methotrexate-induced Acute Hepatotoxicity in Male Rats. Int. J. Pharm. 2018, 14, 1029-1037.

35. Toledo, J.B.; Furlan, A.C.; Pozza, P.C.; Carraro, J.M.; Gabriel, F.S.L.; Gallego, A.G. Reduction of the crude protein content of diets supplemented with essential amino acids for piglets weighing 15 to 30 kilograms. Rev. Bras. Zootec. 2014, 43, 301-309. [CrossRef]

36. Arigony, A.L.; de Oliveira, I.M.; Machado, M.; Bordin, D.L.; Bergter, L.; Prá, D.; Henriques, J.A. The influence of micronutrients in cell culture: A reflection on viability and genomic stability. Biomed Res Int. 2013, 2013, 597282. [CrossRef] [PubMed]

37. El-Desoky, N.I.; Hashem, N.M.; Elkomy, A.; Abo-elezz, Z.R. Physiological response and semen quality of rabbit bucks supplemented with Moringa leaves ethanolic extract during summer season. Animal 2017, 11, 1549-1557. [CrossRef] [PubMed]

38. Bin-Jumah, M.; Abd El-Hack, M.E.; Abdelnour, S.A.; Hendy, Y.A.; Ghanem, H.A.; Alsafy, S.A.; Khafaga, A.F.; Noreldin, A.E.; Shaheen, H.; Samak, D.; et al. Potential use of chromium to combat thermal stress in animals: A review. Sci. Total Environ. 2020, 707, 135996. [CrossRef] [PubMed]

39. Sejian, V.; Singh, A.K.; Sahoo, A.; Naqvi, S.M.K. Effect of mineral mixture and antioxidant supplementation on growth, reproductive performance and adaptive capability of Malpura ewes subjected to heat stress. J. Anim. Physiol. Anim. Nutr. 2014, 98, 72-83. [CrossRef]

(C) 2020 by the authors. Licensee MDPI, Basel, Switzerland. This article is an open access article distributed under the terms and conditions of the Creative Commons Attribution (CC BY) license (http://creativecommons.org/licenses/by/4.0/). 